\title{
Detection of Cryptosporidium parvum oocysts in calf fecal samples by direct immunofluorescence assay
}

\author{
Detecção de oocistos de Cryptosporidium parvum em amostras fecais de bezerros \\ pela reação de imunofluorescência direta \\ Weslen Fabricio Pires Teixeira'; Willian Marinho Dourado Coelho²; \\ Cáris Maroni Nunes ${ }^{1}$; Marcelo Vasconcelos Meireles ${ }^{1 *}$ \\ ${ }^{1}$ Faculdade de Medicina Veterinária, Universidade Estadual Paulista - UNESP \\ ${ }^{2}$ Faculdade de Ciências Agrárias e Veterinárias, Universidade Estadual Paulista - UNESP \\ Received January 24, 2011 \\ Accepted August 23, 2011

\begin{abstract}
The aim of this study was to produce a conjugate containing anti-Cryptosporidium parvum polyclonal antibodies and standardize a Direct Immunofluorescence Assay (DIF) for detecting C. parvum oocysts in fecal samples from calves. In order to obtain anti-C. parvum polyclonal antibodies, two New Zealand rabbits were immunized with a purified solution of $C$. parvum oocysts and Freund's adjuvant. Purification of the immunoglobulin G (IgG) fraction was performed by means of precipitation in ammonium sulfate and chromatography using a DEAE-cellulose column. The anti-C. parvum polyclonal antibody titer was determined by means of the enzyme-linked immunosorbent assay (ELISA). The rabbit anti-C. parvum IgG fraction was conjugated with fluorescein isothiocyanate and standardization of the DIF was performed using various dilutions of conjugate on slides positive for $C$. parvum oocysts. The cross-reactivity of the anti-C. parvum conjugate was tested using oocysts of Cryptosporidium serpentis, Cryptosporidium andersoni, Escherichia coli, Eimeria sp., and Candida sp. An anti-C. parvum conjugate was successfully produced, thus allowing standardization of DIF for detection of Cryptosporidium oocysts in fecal samples. Cross-reactivity of anti-C. parvum polyclonal antibodies with $C$. andersoni and C. serpentis was also observed.
\end{abstract}

Keywords: Direct immunofluorescence, oocysts, Cryptosporidium parvum, fecal samples, cattle.

\section{Resumo}

O objetivo deste estudo foi produzir um conjugado contendo anticorpos policlonais anti-Cryptosporidium parvum e padronizar a Reação de Imunofluorescência Direta (RID), para detecção de oocistos de C. parvum em amostras fecais de bezerros. Para produção de anticorpos policlonais anti-C. parvum, dois coelhos da raça Nova Zelândia foram imunizados com uma soluçáo purificada de oocistos de C. parvum e adjuvante de Freund. A purificação da fração de imunoglobulina $\mathrm{G}$ (IgG) foi realizada por meio de precipitação em sulfato de amônio e cromatografia em coluna de DEAE celulose. A titulaçáo dos anticorpos policlonais anti-C. parvum foi determinada por meio de ensaio imunoenzimático (ELISA). A fração IgG de coelho anti-C. parvum foi conjugada com isotiocianato de fluoresceína, e a padronização da RID foi feita utilizando-se várias diluiçôes do conjugado, em lâminas positivas para C. parvum. Foi pesquisada também a presença de reatividade cruzada do conjugado anti-C. parvum com C. serpentis, $C$. andersoni, Escherichia coli, Eimeria sp. e Candida sp.. A produção do conjugado anti-C. parvum foi bem sucedida, sendo possível a padronizaçáo da RID para detecçáo de oocistos em fezes. Foi também observada reatividade cruzada dos anticorpos policlonais anti-C. parvum, com C. andersoni e C. serpentis.

Palavras-chave: Imunofluorescência direta, oocistos, Cryptosporidium parvum, amostras fecais, bovinos.

\footnotetext{
${ }^{*}$ Corresponding author: Marcelo Vasconcelos Meireles

Faculdade de Medicina Veterinária, Universidade Estadual Paulista - UNESP,

Campus Araçatuba, Rua Clóvis Pestana, 793, Bairro Dona Amélia,

CEP 16050-680, Araçatuba, SP, Brazil

e-mail: marcelo@fmva.unesp.br
} 


\section{Introduction}

Cryptosporidiosis in neonate calves is generally caused by Cryptosporidium parvum, with reports of infections in which up to $6 \times 10^{11}$ oocysts per animal are eliminated during the first month of life (UGA et al., 2000). This represents a risk of transmission to other animals and also to humans, given that $C$. parvum presents high zoonotic potential (XIAO; FAYER, 2008).

The importance of C. parvum as an etiological agent for diarrhea, enteritis and mortality among calves, during their first weeks of life, has already been confirmed by several researchers (SANFORD; JOSEPHSON, 1982; HEINE et al., 1984; GARCIA; LIMA, 1994; SOUZA; LOPES, 1995; FEITOSA et al., 2008).

Among the techniques used to detect Cryptosporidium oocysts in fecal samples, the direct immunofluorescence assay (DIF) is prominent (FAYER et al., 2000; BIALEK et al., 2002; JEX et al., 2008). It has been recognized as presenting better sensitivity and specificity than shown by traditional staining techniques (ARROWOOD; STERLING, 1989; JOHNSTON et al., 2003).

Imported DIF kits using anti-C. parvum monoclonal antibodies labeled with fluorescein thiocyanate exist on the market (GRACZYK et al., 1996). However, the acquisition cost of these products makes it practically impossible to use them in routine laboratory analyses (ALLES et al., 1995; CARVALHO, 2009).

The aim of the present study was to produce a conjugate with anti-C. parvum polyclonal antibodies and standardize DIF for detecting C. parvum oocysts in fecal samples from calves.

\section{Material and Methods}

This study was approved by the Ethics Committee for Animal Use of the Dentistry School of UNESP, Araçatuba Campus, on October 10, 2008, under protocol number 2008-006645.

\section{Production of anti-C. parvum polyclonal antibodies}

Anti-C. parvum polyclonal antibodies were produced in two adult New Zealand rabbits (A and B), by means of an initial intradermal inoculation of a solution containing $3 \times 10^{6}$ intact $C$. parvum oocysts and Freund's complete adjuvant, in proportions of $1: 1$. This was followed by intramuscular inoculation with $2 \times 10^{6}$ oocysts and Freund's incomplete adjuvant, in proportions of 1:1, which was done three, six and eight weeks after the first inoculation (STIBBS; ONGERTH, 1986). The C. parvum oocysts used for the inoculations came from a feces sample from a calf on a dairy farm in the municipality of Araçatuba, state of São Paulo. The oocysts were subjected to the technique of centrifugation-sedimentation in water and ether (MELONI; THOMPSON, 1996), purification in a cesium chloride solution (ARROWOOD; DONALDSON, 1996) and quantification in a Neubauer chamber. The sediment was then stored at $4{ }^{\circ} \mathrm{C}$ in $1 \%$ formalin at pH 7.6 (STIBBS; ONGERTH, 1986).

The Cryptosporidium species present in the inoculum was determined by means of microscopic analysis (morphology and morphometry) and by means of molecular classification using the nested polymerase chain reaction (PCR) to amplify $18 \mathrm{~S}$ rRNA gene fragments (XIAO et al., 2000), with subsequent sequencing of the amplified fragments.

Five days after the last inoculation, the rabbits were anesthetized using acepromazine and sodium thiopental, and blood samples were collected by means of cardiac puncture. The serum was obtained by means of centrifugation of the blood samples at 1,500 rpm, for 5 minutes at $4{ }^{\circ} \mathrm{C}$, and was then stored at $-20{ }^{\circ} \mathrm{C}$ (STIBBS; ONGERTH, 1986).

To ascertain the anti-C. parvum antibody titers before and after oocyst inoculation, the indirect enzyme-linked immunosorbent assay (ELISA) was used. Two aliquots of $1 \mathrm{~mL}$ of serum from each rabbit were stored: one from the day of the first inoculation and the other five days after the last inoculation.

\section{Indirect ELISA for rabbit anti-C. parvum antibody titers}

The antigen used in ELISA was produced from $23 \times 10^{6}$ C. parvum oocysts that were purified in cesium chloride, diluted in PBS ( $\mathrm{pH} 7.4$ ) and sonicated in an ice bath for 10 cycles of ten seconds, with 20-second resting intervals between one cycle and the next. After protein assaying using the $\mathrm{BCA}^{\bullet}$ kit (Sigma, St Louis, USA), the antigen was used at a concentration of $10 \mu \mathrm{g} \cdot \mathrm{mL}^{-1}$.

The serum samples from the rabbits that were collected before and after oocyst inoculation were tested at proportions of 1:1,000 (serum $/ 5 \%$ skimmed milk).

A conjugate composed of anti-rabbit IgG (whole molecule)peroxidase antibody produced in goat (A6154 ; Sigma, St Louis, USA) was used in proportion of 1:5,000 (conjugate $/ 5 \%$ skimmed milk). After 20 minutes of addition of the substrate tetramethylbenzidine (00-2023 ${ }^{\circ}$; Invitrogen, Carlsbad, USA), the enzymatic reaction was stopped with $1 \mathrm{~N} \mathrm{HCl}$. The reactions were read using a microplate reader (Labsystems Multiskan EX), with a $450 \mathrm{~nm}$ filter.

The reactions were read using a microplate reader (Labsystems Multiskan EX), with a $450 \mathrm{~nm}$ filter.

\section{Conjugate production}

To produce the conjugate, serum from rabbit $A$ was used. The gamma-globulin fraction was purified by means of precipitation using $35 \%$ ammonium sulfate ( $70 \%$ ammonium sulfate solution diluted in proportions of 1:1 with rabbit serum) and centrifugation at 7,000 g, for 30 minutes. The resultant sediment was diluted in $3 \mathrm{~mL}$ of $0.01 \mathrm{M}$ PBS ( $\mathrm{pH}$ 7.2), placed on a dialysis membrane and immersed in $0.025 \mathrm{M}$ Tris- $\mathrm{HCl}$ buffer ( $\mathrm{pH} 8.8$ ) for 18 hours, in order to remove the excess ammonium sulfate (HERBERT et al., 1973).

The IgG fraction was obtained by means of ion-exchange chromatography in a column using DEAE-cellulose gel (CORTHIER et al., 1984), and protein assaying of the gammaglobulin fraction and IgG fraction was carried out using the $\mathrm{BCA}^{\circ}$ kit (Sigma, St Louis, USA).

The reactivity of the anti-C. parvum $\operatorname{IgG}$ fraction was tested by means of indirect ELISA, in proportions of 1:400 (IgG/5\% skimmed milk). After the reactivity of the IgG fraction against antigens of C. parvum had been proven, this fraction was conjugated with 
fluorescein isothiocyanate (Sigma, St Louis, USA), by means of diluting $15 \mathrm{~mL}$ of the $\mathrm{IgG}$ fraction from rabbit A in $3 \mathrm{~mL}$ of $0.5 \mathrm{M}$ carbonate-bicarbonate buffer ( $\mathrm{pH}$ 9.5). To this solution, $1.46 \mathrm{mg}$ of fluorescein isothiocyanate was added $(0.02 \mathrm{mg}$ for each $\mathrm{mg}$ of protein contained in the rabbit IgG sample), with incubation at $4{ }^{\circ} \mathrm{C}$, overnight.

Purification of the conjugated antibody was done in a Sephadex G25 gel column (Sigma, St Louis, USA), in the proportions of $1 \mathrm{~cm}$ of gel in the column for each $1 \mathrm{~mL}$ of conjugate sample.

The solution containing the conjugate was divided into aliquots of $2 \mathrm{~mL}$ in amber tubes and was frozen at $-20{ }^{\circ} \mathrm{C}$.

\section{Direct immunofluorescence assay}

The slides used for DIF were firstly treated with polylysine (Sigma, St Louis, USA), diluted in the proportions of 1:20, in deionized water (ARROWOOD et al., 1991). To this, $25 \mu \mathrm{L}$ of purified feces sample that was positive for $C$. parvum oocysts (conserved in 10\% buffered formalin in the proportion of 1:3) was added. The sample drop was left to dry out completely at room temperature. Subsequently, $25 \mu \mathrm{L}$ of anti-C. parvum conjugate was added at several dilutions (1:40, 1:80 and 1:100), in $0.01 \mathrm{M}$ PBS (pH 7.2) and 4'.6'-diamidine-2-phenylindole (DAPI) $(50 \mu \mathrm{l}$ of DAPI at $2 \mathrm{mg} \cdot \mathrm{mL}^{-1}$ to $50 \mathrm{~mL}$ of $0.01 \mathrm{M} \mathrm{PBS}, \mathrm{pH} 7.2$ ), and the slide was incubated at $37^{\circ} \mathrm{C}$ for 30 minutes, in a damp chamber. At the end of the incubation, the sample was washed using $0.01 \mathrm{M}$ PBS ( $\mathrm{pH} 7.2$ ), and the slide mounting was completed using a cover slip over $25 \mu \mathrm{L}$ of mounting buffer (90\% glycerol in $0.01 \mathrm{M}$ PBS, pH 7.2; 0.1 mg. $\mathrm{mL}^{-1}$ of p-phenylenediamine) (PLATT; MICHAEL, 1983).

The reaction was read under an Olympus BX-50 microscope with a $100 \mathrm{~W}$ mercury light bulb and the U-MWU2 filter (DAPI) and U-MWU2-B filter (fluorescein), at a magnification of $400 \times$.

\section{Determination of DIF specificity}

Confirmation of the diagnosis obtained by means of DIF was achieved by means of microscopic examination using differential interference contrast (DIC) and staining with 4',6'-diamidine-2phenylindole (DAPI) (SMITH et al., 2002).

Using the same DIF methodology as for C. parvum oocysts, the presence of cross-reactivity of anti-C. parvum IgG with Escherichia coli, Eimeria sp., Candida sp. and other species of Cryptosporidium (C. andersoni and C. serpentis) was investigated. The $C$. andersoni and $C$. serpentis oocysts were isolated, respectively, from fecal samples from a calf on a dairy farm in the municipality of Muritinga do Sul, state of São Paulo, and from a royal python (Python regius) from the city of São Paulo, state of São Paulo. These samples were subjected to the same purification and classification methods as used for the inoculum that was destined for production of anti-C. parvum polyclonal antibodies.

\section{Results}

The volumes of serum samples obtained from rabbits A and B were respectively 36 and $39 \mathrm{~mL}$. The protein concentration and
Table 1. Concentration of gamaglobulins and immunoglobulin G (IgG) in serum of rabbits inoculated with oocysts of $C$. parvum.

\begin{tabular}{cccccc}
\hline \multirow{2}{*}{ Rabbits } & \multicolumn{2}{c}{ Gamaglobulins } & & \multicolumn{2}{c}{ IgG } \\
\cline { 2 - 3 } \cline { 5 - 6 } & $\begin{array}{c}\text { Serum } \\
\text { volume } \\
(\mathbf{m L})\end{array}$ & $\begin{array}{c}\text { Concentration } \\
\left(\mathbf{m g} \cdot \mathbf{m L}^{-1}\right)\end{array}$ & & $\begin{array}{c}\text { Serum } \\
\text { volume } \\
(\mathbf{m L})\end{array}$ & $\begin{array}{c}\text { Concentration } \\
\left(\mathbf{m g} \cdot \mathbf{m L}^{-1}\right)\end{array}$ \\
\hline $\mathrm{A}$ & 4.5 & 43.91 & & 30 & 4.87 \\
$\mathrm{~B}$ & 5.5 & 22.62 & & 15 & 4.42 \\
\hline
\end{tabular}

Table 2. Results of the enzyme-linked immunosorbent assay (ELISA) in serum samples of rabbits, before and after inoculation with oocysts of C. parvum, and in the fractions of immunoglobulin $\mathrm{G}(\mathrm{IgG})$ obtained from the two rabbits.

\begin{tabular}{cccc}
\hline Rabbits & \multicolumn{3}{c}{ Absorbance } \\
\cline { 2 - 3 } & \multicolumn{2}{c}{ Serum } \\
\cline { 2 - 3 } & $\begin{array}{c}\text { Before } \\
\text { inoculation }\end{array}$ & $\begin{array}{c}\text { After } \\
\text { inoculation }\end{array}$ \\
\hline A & 0.270 & 2.444 & 0.877 \\
B & 0.262 & 1.655 & 0.730 \\
\hline
\end{tabular}

ELISA results from the gamma-globulin fraction and purified IgG fraction in a DEAE-cellulose column showed that rabbit A yielded greater production of antibodies than did rabbit B (Table 1).

Table 2 describes the results from ELISA performed on the rabbit serum collected before and after inoculation of $C$. parvum oocysts and on the purified IgG fraction in the DEAE-cellulose column.

The total volume of conjugate produced was $12 \mathrm{~mL}$, and the proportions of 1:80 were used for the dilution. This dilution enabled the best results with regard to viewing the $C$. parvum oocysts.

The fluorescence observed in the $C$. parvum oocysts emanated mainly from their walls (Figure 1). In the DIF specificity test, the conjugate did not present any cross-reactivity with $E$. coli, Eimeria sp. or Candida sp. On the other hand, cross-reactivity was found with $C$. andersoni and $C$. serpentis.

\section{Discussion}

The volume of the $\mathrm{IgG}$ fraction from rabbit A was greater than that of rabbit $B$. This was because the peak elimination of $\operatorname{IgG}$ in the purification process for the gamma-globulin fraction of rabbit A was greater than that of rabbit $B$, thereby increasing the length of the procedure and resulting in greater dilution of the sample in $0.025 \mathrm{M}$ Tris- $\mathrm{HCl}$ buffer $(\mathrm{pH} 8.8)$, consequent to the greater protein concentration of the gamma-globulin fraction in rabbit $\mathrm{A}$.

The inoculums through intradermal and intramuscular routes, with solution of intact $C$. parvum oocysts were performed with the aim of promoting production of antibodies against antigens that are present in the walls of the oocysts. This binding could be proven through DIF, in which it was observed that the fluorescence of the oocysts emanated from their walls. However, in the present 


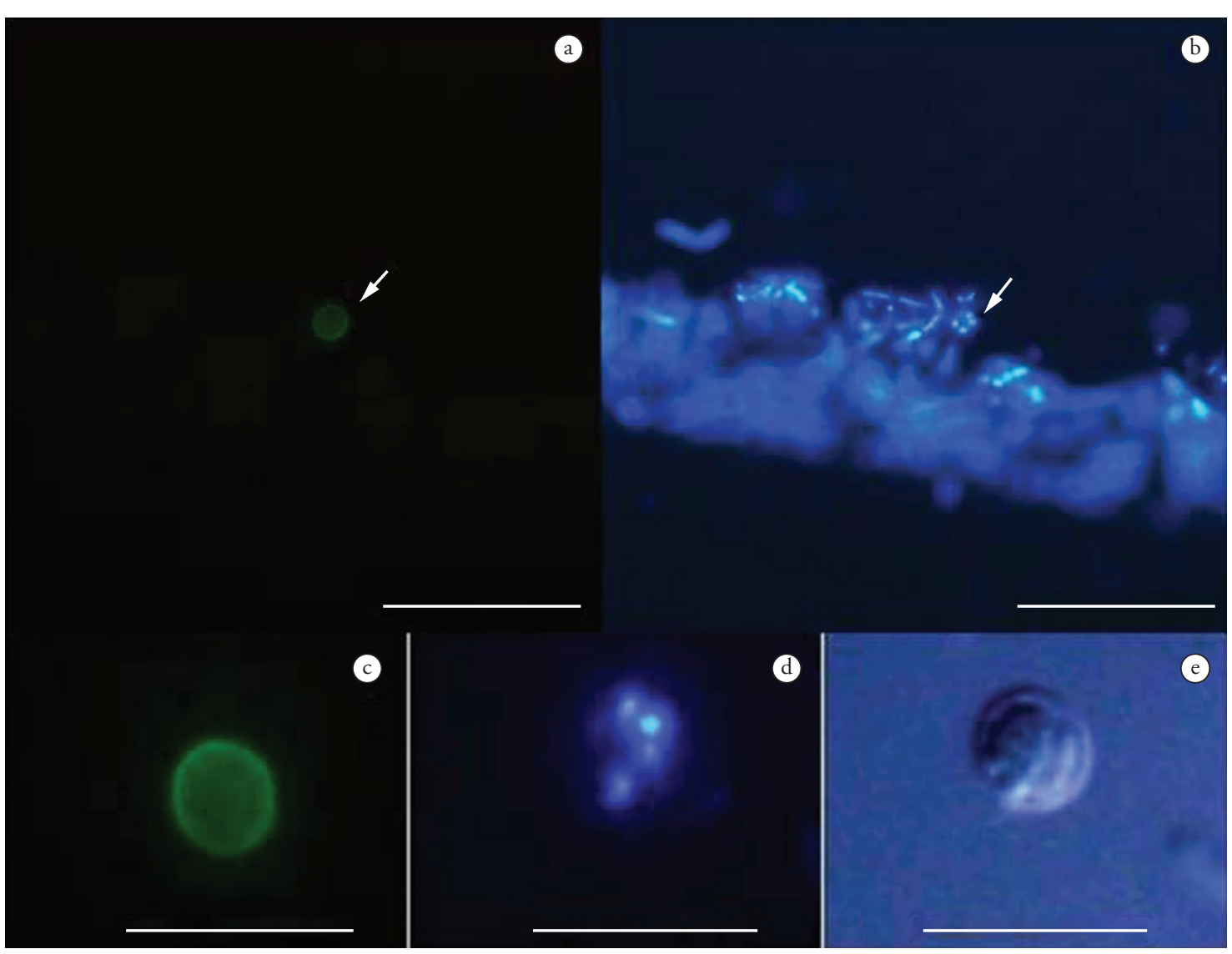

Figure 1. Oocysts of $C$. parvum. a) direct immunofluorescence (Bar $=20 \mu \mathrm{m})$; b) same microscopic field from A, staining with DAPI $($ Bar $=20 \mu \mathrm{m})$; c, d and e) same microscopic field, respectively, direct immunofluorescence, staining with DAPI and differential interference contrast $(\mathrm{Bar}=10 \mu \mathrm{m})$.

study, the affinity of anti-C. parvum antibodies for the internal structures of the oocysts was not tested.

The conjugate was used at a dilution of 1:80, in PBS ( $\mathrm{pH} 7.4)$, with good levels of fluorescence of oocysts, such that the fluorescence only diminished at the dilution of 1:100. Stibbs and Ongerth (1986) standardized the indirect immunofluorescence assay for detecting Cryptosporidium sp. oocysts in fecal samples from monkeys and humans, and they achieved the best results in relation to oocyst fluorescence at conjugate dilutions of 1:20, 1:40 and 1:60 in PBS ( $\mathrm{pH}$ 7.6), with a considerable decrease at the dilution of 1:80.

The conjugate at the dilution of 1:80 made it possible to carry out DIF in duplicate, on 1.6 feces samples from calves, with a volume of only $1 \mu \mathrm{L}$. In other words, with $12 \mathrm{~mL}$ of anti-C. parvum conjugate produced from $15 \mathrm{~mL}$ of sample from the IgG fraction of rabbit A, it would be possible to carry out analyses in duplicate on 19, 200 samples. This would considerably decrease the cost of this procedure in comparison with the cost of using commercial kits.

The absence of cross-reactivity of the polyclonal antibodies used in this study, with other etiological agents, corroborates the results obtained by Graczyk et al. (1996). These authors investigated the specificity of the monoclonal antibody used in the Merifluor Cryptosporidium/Giardia DIF kit (Meridian Diagnostics, Cincinnati, USA), for detecting Cryptosporidium, and did not observe any cross-reactivity with samples containing eggs from eight helminth species, three species of Eimeria, sporocysts of Sarcocystis cruzi and two isolates of Candida sp. These authors also tested for the presence of cross-reactivity with other species of Cryptosporidium (C. serpentis, C. meleagridis, C. wrairi, C. muris and $C$. muris-like) and observed cross-reactivity with all the species tested. These findings are similar to those of the present study, in which the conjugate presented cross-reactivity with $C$. serpentis and $C$. andersoni.

Stibbs and Ongerth (1986) did not observe any nonspecific binding of anti-Cryptosporidium sp. polyclonal antibodies, when tested against Candida albicans, Giardia lamblia, Entamoeba histolytica, Giardia sp., Entamoeba sp. and Blastocystis hominis. However, nonspecific binding of anti-Cryptosporidium antibodies occurred with oocysts of Eimeria sp. and Caryospora, which did not occur with any of the etiological agents tested in the present study.

\section{Conclusions}

An anti-C. parvum conjugate containing antibodies originating in a rabbit was successfully produced, thus making it possible to standardize DIF for detecting C. parvum oocysts in fecal samples.

No cross-reactivity was observed between the conjugate produced and Escherichia coli, Eimeria sp. and Candida sp. 
The anti-C. parvum conjugate presented cross-reactivity with C. andersoni and C. serpentis, which enables its use for detecting oocysts from other Cryptosporidium species in fecal samples.

\section{Acknowledgements}

We would like to thank Fundação de Amparo à Pesquisa do Estado de São Paulo (FAPESP) for the following grants: financial support (2008/57380-1).

\section{References}

ALLES, A. J. et al. Prospective comparison of direct immunofluorescence and conventional staining methods for detection of Giardia and Cryptosporidium spp. in human fecal specimens. Journal of Clinical Microbiology, v. 33, n. 6, p. 1632-1634, 1995. PMid:7544365. PMCid:228230

ARROWOOD, M. J.; DONALDSON, K. Improved purification methods for calf-derived Cryptosporidium parvum oocysts using discontinuous sucrose and cesium chloride gradients. Journal of Eukaryotic Microbiology, v. 43, n. 5, p. 89S, 1996. PMid:8822880. http://dx.doi.org/10.1111/j.1550-7408.1996.tb05015.x

ARROWOOD, M. J.; STERLING, C. R. Comparison of conventional staining methods and monoclonal antibody-based methods for Cryptosporidium oocyst detection. Journal of Clinical Microbiology, v. 27, n. 7, p. 1490-1495, 1989. PMid:2475523. PMCid:267601.

ARroWOOD, M. J.; STERling, C. R.; HEALEY, M. C. Immunofluorescent microscopical visualization of trails left by gliding Cryptosporidium parvum sporozoites. Journal of Parasitology, v. 77, n. 2, p. 315-317, 1991. PMid:2010865. http://dx.doi.org/10.2307/3283104

BIALEK, R. et al. Comparison of fluorescence, antigen and PCR assays to detect Cryptosporidium parvum in fecal specimens. Diagnostic Microbiology and Infectious Disease, v. 43, n. 4, p. 283-288, 2002. http://dx.doi.org/10.1016/S0732-8893(02)00408-X

CARVALHO, T. T. R. Estado atual do conhecimento de Cryptosporidium e Giardia. Revista de Patologia Tropical, v. 38, n. 1, p. 1-16, 2009.

CORTHIER, G.; BOSCHETTI, E.; CHARLEY-POULAIN, J. Improved method for IgG purification from various animal species by ion exchange chromatography. Journal of Immunological Methods, v. 66, n. 1, p. 75-79, 1984. http://dx.doi.org/10.1016/0022-1759(84)90249-7

FAYER, R.; MORGAN, U.; UPTON, S. J. Epidemiology of Cryptosporidium: Transmission, detection and identification. International Journal for Parasitology, v. 30, n. 12-13, p. 1305-1322, 2000. http://dx.doi.org/10.1016/S0020-7519(00)00135-1

FEITOSA, F. L. F. et al. Importância de Cryptosporidium spp. como causa de diarréia em bezerros. Pesquisa Veterinária Brasileira, v. 28 , n. 10 , p. $452-456,2008$. http://dx.doi.org/10.1590/S0100736X2008001000002

GARCIA, A. M.; LIMA, J. D. Prevalência de Cryptosporidium spp. em rebanhos leiteiros de Pará de Minas $(\mathrm{MG})$ e sua relação com práticas de manejo. Revista Brasileira de Parasitologia Veterinária, v. 3, n. 1, p. 23-28, 1994.

GRACZYK, T. K.; CRANFIELD, M. R.; FAYER, R. Evaluation of commercial enzyme immunoassay (EIA) and immunofluorescent antibody (IFA) test kits for detection of Cryptosporidium oocysts of species other than Cryptosporidium parvum. American Journal of Tropical Medicine and Hygiene, v. 54, n. 3, p. 274-279, 1996. PMid:8600765.
HEINE, J. et al. Enteric lesions and diarrhea in gnotobiotic calves monoinfected with Cryptosporidium species. Journal of Infectious Diseases, v. 150, n. 5, p. 768-775, 1984. PMid:6491380. http://dx.doi. org/10.1093/infdis/150.5.768

HERBERT, G. A.; PELHAM, P. L.; PITTMAN, B. Determination of the optimal ammonium sulfate concentration for the fractionation of rabbit, sheep, horse, and goat antisera. Applied Microbiology, v. 25, n. 1, p. 26-36, 1973. PMid:4119831. PMCid:380730.

JEX, A. R. et al. Cryptosporidium - Biotechnological advances in the detection, diagnosis and analysis of genetic variation. Biotechnology Advances, v. 26, n. 4, p. 304-317, 2008. PMid:18430539. http://dx.doi. org/10.1016/j.biotechadv.2008.02.003

JOHNSTON, S. P. et al. Evaluation of three commercial assays for detection of Giardia and Cryptosporidium organisms in fecal specimens. Journal of Clinical Microbiology, v. 41, n. 2, p. 623-626, 2003. PMid:12574257. PMCid:149727. http://dx.doi.org/10.1128/ JCM.41.2.623-626.2003

MELONI, B. P.; THOMPSON, R. C. A. Simplified methods for obtaining purified oocysts from mice and for growing Cryptosporidium parvum in vitro. Journal of Parasitology, v. 82, n. 5, p. 757-762, 1996. PMid:8885885. http://dx.doi.org/10.2307/3283888

PLATT, J. L.; MICHAEL, A. F. Retardation of fading and enhancement of intensity of immunofluorescence by p-phenylanediamine. The Journal of Histochemistry and Cytochemistry, v. 31, n. 6, p. 840-842, 1983. http://dx.doi.org/10.1177/31.6.6341464

SANFORD, S. E.; JOSEPHSON, G. K. A. Bovine cryptosporidiosis: clinical and pathological findings in forty-two scouring neonatal calves. Canadian Veterinary Journal, v. 23, n. 12, p. 343-347, 1982. PMid:17422204. PMCid:1790278.

SMITH, H. V. et al. Significance of enhanced morphological detection of Cryptosporidium sp. oocysts in water concentrates determined by using $4^{\prime}, 6^{\prime}$-diamidino-2-phenylindole and immunofluorescence microscopy. Applied and Environmental Microbiology, v. 68, n. 10, p. 5198-5201, 2002. PMid:12324377. PMCid:126443. http://dx.doi. org/10.1128/AEM.68.10.5198-5201.2002

SOUZA, J. C. P.; LOPES, C. W. G. Criptosporidiose em bezerros de rebanhos da bacia leiteira Sul-Fluminense, Estado do Rio de Janeiro. Revista Brasileira de Parasitologia Veterinária, v. 4, n. 1, p. 33-36, 1995.

STIBBS, H. H.; ONGERTH, J. E. Immunofluorescence detection of Cryptosporidium oocysts in fecal smears. Journal of Clinical Microbiology, v. 24, n. 4, p. 517-521, 1986. PMid:2429982. PMCid:268962.

UGA, S. et al. Prevalence of Cryptosporidium parvum infection and pattern of oocyst shedding in calves in Japan. Veterinary Parasitology, v. 94 , n. 1-2, p. 27-32, 2000. http://dx.doi.org/10.1016/S03044017(00)00338-1

XIAO, L.; FAYER, R. Molecular characterisation of species and genotypes of Cryptosporidium and Giardia and assessment of zoonotic transmission. International Journal for Parasitology, v. 38, n. 11, p. 1239-1255, 2008. PMid:18479685. http://dx.doi.org/10.1016/j. ijpara.2008.03.006

XIAO, L. et al. Identification of species and sources of Cryptosporidium oocysts in storm waters with a small-subunit rRNA-based diagnostic and genotyping tool. Applied and Environmental Microbiology, v. 66, n. 12, p. 5492-5498, 2000. PMid:11097935. PMCid:92489. http://dx.doi.org/10.1128/AEM.66.12.5492-5498.2000 